\title{
Environmental Influence on Life-History Traits in Male Squid Uroteuthis Edulis With Alternative Reproductive Tactics
}

\section{Yumeng Pang ( $\nabla$ yumeng.pang@aori.u-tokyo.ac.jp )}

Atmosphere and Ocean Research Institute

Chih-Shin Chen

National Taiwan Ocean University

Tomohiko Kawamura

The University of Tokyo

\section{Yoko Iwata}

The University of Tokyo

\section{Research Article}

Keywords: Environmental influence, life-history traits, male squid Uroteuthis edulis, alternative reproductive tactics, oceanic parameters, temperatures

Posted Date: November 2nd, 2021

DOI: https://doi.org/10.21203/rs.3.rs-1002647/v1

License: (9) This work is licensed under a Creative Commons Attribution 4.0 International License. Read Full License

Version of Record: A version of this preprint was published at Marine Biology on February 3rd, 2022. See the published version at https://doi.org/10.1007/s00227-022-04017-y. 


\section{Abstract}

Squid are characterized by flexible life-history traits (LHTs) that change in response to changing oceanic parameters. Male alternative reproductive tactics (ARTs), characterized by large-sized 'consorts' versus small-sized 'sneakers', are commonly observed in loliginid species. This study reports on LHTs flexibility in male squids displaying ARTs. LHTs of consorts and sneakers in Uroteuthis edulis, including body size, age, growth rate and gonado-somatic energy allocation, were compared among seasonal and geographical groups from Japan and Taiwan. The ratio of consorts to sneakers was highest in the group spawning in the 'Japan-warm' season (June-November), followed by that of the 'Japan-cold' season (December-May), and lowest in Taiwan (spring and autumn). LHTs were compared among cohorts separated by hatching season and catch location (Jwarm, Jcold and Taiwan cohorts). Mean body size of consorts showed no difference among cohorts, although Taiwan consorts were relatively younger than Japan consorts. Mean size and age of sneakers decreased with increased water temperature at hatching. Growth rates of consorts and sneakers were slightly different among cohorts, in accordance with differences of statolith increment widths during their early life stage (50-150 d). Growth rates of both consorts and sneakers were highest in the Taiwan cohort, followed by the Jwarm cohort, with the Jcold cohort lowest. Sneakers invested more both in mantle and gonadal weights than consorts in all cohorts. Gonado-somatic energy allocation patterns of consorts and sneakers were consistent at different temperatures. LHTs of $U$. edulis consorts and sneakers were strongly influenced by temperature, with higher flexibility in sneakers than consorts.

\section{Introduction}

Considerable flexibility in squid life-history traits (LHTs) has been assumed to be one of the pivotal factors contributing to the increase of squid stocks worldwide, which appears to be a result of the ability of squids to adapt successfully to environmental changes (Pecl et al., 2004; Pecl and Jackson, 2005; Hoving et al., 2013; Doubleday et al., 2016). There is great variability in LHTs in a wide range of squid species (Pierce et al., 2005; Ichii et al., 2009; Ching et al., 2019), which is considered to be a mixture of intrinsic variability and the influence of environmental factors, especially water temperature and food availability (Vidal et al., 2002; Pecl and Jackson, 2005; Pierce et al., 2008; Yu et al., 2015). Significant differences in growth and size-at-maturity have been observed in different geographical and seasonal cohorts for various squid species (Arkhipkin et al., 2000; Jackson and Moltschaniwskyj, 2002; Jackson et al., 2003; Ceriola and Jackson, 2010). For example, squid that hatch in warmer temperatures grow faster and mature earlier than those in colder waters (Jackson and Moltschaniwskyj, 2002; Moreno et al., 2007; Ibáñez et al., 2015; Chemshirova et al., 2021), indicating the strong influence of environmental conditions on squid growth and maturation, particularly during the early life stages (Vidal et al., 2002; Chen and Chiu, 2003; Forsythe, 2004). In addition, energy allocation between somatic growth and reproduction also exhibits great variation (McGrath Steer and Jackson, 2004; Pecl et al., 2004). Many squid species continue to grow after reproductive maturation (Arkhipkin et al., 1999; Wang et al., 2010), but energy allocation to somatic growth decreases progressively (Forsythe, 2004). Reproductive investment varies 
and could be a function of the environmental conditions experienced, especially during the hatching period (Pecl and Moltschaniwskyj, 2006).

Large sex-specific differences in LHTs are common in many squid species (Arkhipkin, 1996; Jackson et al., 2005). Male squids vary more in somatic growth while females vary more in reproductive investment, since males tend to invest more energy in somatic growth to fight for mating opportunities while females invest more in egg production (McGrath Steer and Jackson, 2004; Pecl et al., 2004; Lin et al., 2015). These differences are more complex in coastal loliginid squid species, which typically display male dimorphism associated with two alternative reproductive tactics (ARTs) (Iwata and Sakurai, 2007; Iwata et al. 2018; Apostólico and Marian, 2018, Marian et al., 2019). One type of male ART is the 'consort', where the male is generally larger than mature females and therefore has an advantage when competing for females with larger body size. Consorts conduct 'male-parallel' copulations with high fertilization success (Hanlon et al., 1997; Iwata et al. 2005, Naud et al. 2016, Shashar and Hanlon, 2013). The other male ART is the 'sneaker', where the male is generally smaller than mature females and avoids male-male competition and courtship behaviors. Sneakers conduct 'head-to-head' copulations which result in a lower number of egg fertilizations per female than that of consorts (Hanlon et al., 1997; Iwata et al., 2005, Naud et al. 2016, Shashar and Hanlon, 2013).

In Loligo vulgaris and L. forbesi, smaller and younger mature males have a high gonado-somatic index (GSI), with relatively large gonads but small spermatophores; while larger and older males have a low GSI, with a small gonad but large spermatophores (Rocha and Guerra, 1996). Gonadal investment is also higher in sneaker males than in consort males in Doryteuthis plei (Apostólico and Marian, 2019) but the opposite is true in Heterololigo bleekeri, and there are no differences in GSI between consorts and sneakers in L. reynaudii (Iwata et al. 2021). Although a proximate mechanism of squid male dimorphism associated with ARTs remains elusive, it is crucial to distinguish male squids by ARTs when it comes to understanding correctly about the response of male squid LHTs to different environmental conditions, due to the intrinsic differences in body size and reproductive characters between males using one or other of the two different ARTs.

The swordtip squid Uroteuthis edulis is an ideal model species to study the effects of environmental conditions on the LHTs of males with ARTs. Firstly, U. edulis is distributed widely, from southern Japan, across the South China Sea to the Philippine Islands and perhaps even the continental shelf of northern Australia (Jereb and Roper, 2010). This wide distribution from a temperate area with strong seasonality of water temperature to a stable warm subtropical area provides contexts to study environmental impacts on the LHTs in natural populations. Secondly, $U$. edulis is a commercially important fishery species based in the northwestern Pacific area (FAO 2016), which allows easy access to abundant samples with a wide size range throughout the year. Thirdly, previous studies have shown great variability in U. edulis LHTs in different environments. Female squids in Japanese populations have a higher growth rate when they hatch in a warm season than they do if they hatch in a cold season, and they mature at a younger age and smaller size in Taiwan than in Japan (Pang et al., 2020). Also, in Japanese waters, male squids that hatch in a warm season display a higher growth rate than those hatching in a cold season (Natsukari et 
al. 1988); and male squids in northern Taiwan caught in spring mature at a smaller size than those caught in autumn (Wang et al., 2008). However, these previous studies considered all mature male squids as one group. To investigate male $U$. edulis LHTs in a holistic way, the ART adopted by each male should be taken into consideration. In addition, by also comparing the LHTs of male $U$. edulis off Japan and Taiwan simultaneously, this would contribute to a better understanding of the environmental influences on this species.

Therefore, this study focuses on variations in LHTs of male $U$. edulis squids with two ARTs (consort and sneaker) in terms of growth, maturation and gonado-somatic energy allocation. To identify the impacts of different environments on the variability of male LHTs, individuals collected in the temperate waters of southern Japan and the subtropical waters of northern Taiwan were compared within each year group.

\section{Materials And Methods \\ 2.1 Sampling}

Samples of Uroteuthis edulis Hoyle, 1885, from Japanese waters were collected each month from May 2017 to August 2020, using inshore set-nets located off northern Tsushima Island (depth 30-36 m, $34.33-34.39^{\circ} \mathrm{N}, 129.17-129.30^{\circ} \mathrm{E}$, Figure 1). Fishermen separated the squid into six size classes, with about $4 \mathrm{~kg}$ of squid sampled from each size class (about 15 individuals for the largest class and 120 for the smallest). Measurement data were scaled by the total catch weight of each size class on any given sampling date to avoid size selection biases. Squid from Taiwanese waters were obtained by bottomtrawl during two main spawning seasons in May-July and September-November from 2017 to 2019, at $110 \mathrm{~m}$ depth in the southern East China Sea $\left(25.50-26.00^{\circ} \mathrm{N}, 121.50-122.50^{\circ} \mathrm{E}\right.$, Figure 1$)$. As the catches in Taiwan were small and unsorted, all collected squid were taken to the lab as samples for further analysis.

Sea surface temperature (SST) in the waters off northern Taiwan is warmer and less variable throughout the year $\left(19.7^{\circ} \mathrm{C}-29.7^{\circ} \mathrm{C}\right.$, mean $\left.25.2^{\circ} \mathrm{C}\right)$ compared to that in the waters off southern Japan, which is cooler and more variable between months $\left(14.4^{\circ} \mathrm{C}-29.2^{\circ} \mathrm{C}\right.$, mean $20.7^{\circ} \mathrm{C}$; Japan Meteorological Agency, Fukuoka Regional Headquarters (undated)). Monthly catch data of Japanese squid were divided into two spawning groups on the basis of annual mean SST: a Japan cold-spawning group (JCSG, DecemberMay) and a Japan warm-spawning group (JWSG, June-November). All squid collected from Taiwan were considered as a single spawning group (TSG): the SST in this area had a similar range to that of the JWSG.

\subsection{Biological data and age determination}

For each $U$. edulis male squid, measurements were taken of mantle length ( $\mathrm{ML}$, to the nearest $1 \mathrm{~mm})$, body weight (BW, wet-weight to the nearest g), mantle weight (MW, wet-weight of the muscular mantle and fins, stripped of the head, arms, internal organs and gladius, to the nearest $\mathrm{g}$ ), and total gonad weight (GW, sum of testis weight and accessory gland weight, to the nearest $0.1 \mathrm{~g}$ ). Statoliths were removed 
from each individual, cleaned with distilled water, air dried and stored in microtubes until processing. Sexual maturity stages were categorized based on the three stages reported for Loligo plei (Perez et al., 2002). Mature males of $U$. edulis were classified as either consort or sneaker, according to the shape of their spermatangia (Iwata and Sakurai, 2007; Apostólico and Marian, 2018; Iwata et al., 2018). For each spawning group, the proportion of mature individuals was determined, along with the ratio of consorts to sneakers among them (Table 1).

Table 1

Male $U$. edulis composition of the three sampled spawning groups (JWSG, Japan-warm spawning group; JCSG, Japan-cold spawning group; TSG, Taiwan spawning group).

\begin{tabular}{|c|c|c|c|c|c|c|}
\hline \multirow[t]{2}{*}{ Spawning group } & \multicolumn{4}{|c|}{ Number of sampled individuals } & \multirow[t]{2}{*}{ C:S ratio } & \multirow[t]{2}{*}{ Mature: Total } \\
\hline & Total & Immature & Consorts & Sneakers & & \\
\hline JWSG & 6184 & 3025 & 2245 & 914 & 2.456 & 0.511 \\
\hline JCSG & 4944 & 2767 & 672 & 1505 & 0.447 & 0.440 \\
\hline TSG & 709 & 210 & 49 & 450 & 0.109 & 0.697 \\
\hline
\end{tabular}

Growth increments on the statoliths of $U$. edulis are assumed to be deposited daily (Natsukari et al. 1988), as in other loliginid squids (Patterson 1988; Villanueva 2000; Jackson and Forsythe 2002; Jackson 2004; Arkhipkin 2005). Representative sub-samples were selected from across the size distribution of male squids for statolith microstructure analysis and age determination. Statoliths were attached to a microscope slide using Crystalbond 509, ground on both sides along a transverse plane using fine waterproof sandpapers (\#1000-4000), and polished with cloth before observation. Statolith microstructure was examined by light microscope under transmitted light at $\times 400$ magnification. The hatching ring was defined as the first thick black ring around the nucleus (Arkhipkin, 2005). Growth increments of each statolith were manually read from the hatching ring to the edge of the rostrum using a light microscope connected to a video monitor and an otolith reading system (Otolith 8 software, Ratoc System Engineering Co., Ltd.). The statolith growth increments were counted twice, with an interval of at least 3 months between readings. Only when the counts differed by less than $10 \%$, the mean of the two counts was used as the estimated squid age in days. When increment definition was poor, or the statolith was over-ground, the sample was discarded.

Individual hatching dates were back-calculated from the date of capture, using estimated age at capture as determined by statolith growth increments. According to the hatching dates, males from Japanese waters were grouped into a Japan-cold cohort (Jcold, hatching between December and May) and a Japan-warm cohort (Jwarm, hatching between June and November). As statolith increment width reflects the growth rate of the individual on each day (Arkhipkin, 2005), a statolith 10-day mean increment width and standard deviation were calculated for consorts and sneakers from all cohorts to observe changes of growth rate throughout the life of the cohort.

\subsection{Data analysis}


Instantaneous growth rate in $\mathrm{ML}\left(\mathrm{G}_{\mathrm{L}}\right)$ and $\mathrm{BW}\left(\mathrm{G}_{W}\right)$ was calculated for each male using the following formulae:-

$\mathrm{G}_{\mathrm{L}}=\left(\ln L-\ln L_{0}\right) /\left(T-T_{0}\right) \cdot 100$

$\mathrm{G}_{\mathrm{W}}=\left(\ln W-\ln W_{0}\right) /\left(T-T_{0}\right) \cdot 100$

where $L$ is $M L(m m), W$ is BW $(\mathrm{g})$ and $T$ is time $(\mathrm{d})$ at capture. The $M L$ at hatching $\left(L_{0}\right)$ of $U$. edulis is 2.2 $\mathrm{mm}$ (Toyofuku and Wada, 2018). There are no reports of BW at hatching $\left(W_{0}\right)$ in this species, so it was assumed to be $1.7 \mathrm{mg}$ based on the mean wet weight of ripe eggs in $U$. edulis (Pang et al., 2020). The growth rates for each maturity status among the different cohorts, and for each cohort among different maturity statuses, were compared using one-way ANOVA and Tukey's pairwise post-hoc test.

Two geometric regression models were used to analyze gonado-somatic energy allocation. For each regression, log-transformed ML was used as the independent variable, and either log-transformed MW or GW was the dependent variable. The standardized residual of MW or GW was calculated for each individual by subtracting the predicted value of the geometric model from the actual log-transformed MW or GW at the same value of log-transformed ML. These provide size-independent estimates of the relative condition of somatic or gonadal tissues. Thus, individuals with a higher MW or GW for their length, and accordingly higher residuals, were considered to show better body condition (BC) or reproductive condition (RC), respectively, in terms of somatic or gonadal growth. Two scenarios were analyzed: (1) Geometric regression models were conducted within each cohort, gonado-somatic energy allocation was compared among immature males, consorts and sneakers, and used one-way ANOVA and pairwise post hoc test (Tukey method) to observe the difference in energy allocation; (2) Geometric regression models were conducted within each ART, data from different cohorts were applied to understand the influence of temperature on gonado-somatic allocation by one-way ANOVA and Tukey's pairwise post-hoc test. To determine if energy allocation to somatic and gonadal tissues was a function of an energetic trade-off in different environments, the standardized residuals derived from the ML versus MW (abbreviated below as 'ML-MW') and ML versus GW ('ML-GW') relationships of each cohort were compared for consorts and sneakers using Pearson correlation analysis.

\section{Results}

\subsection{Catch information and hatching period}

A higher proportion of mature individuals was found in the warmer environments: the TSG had the highest proportion of mature individuals, followed by JWSG, with JCSG the lowest. The ratio of consorts to sneakers in each cohort differed greatly, with relatively more consorts in the Jwarm cohort, followed by the Jcold cohort, and relatively few in the Taiwan cohort (Table 1). 
In the Japanese cohorts, the majority of consorts hatched during the warm period and matured mostly in the next warm period. Sneakers hatched throughout the warm and cold periods but more sneakers were always caught in the cold period than the warm (Table 2). In the Taiwanese population, the hatching months of consorts and sneakers largely overlapped.

Table 2. Size and age characteristics of sampled individuals of different hatching cohorts in each spawning group.

(a) Consorts

\begin{tabular}{|c|c|c|c|c|}
\hline Cohort & $\begin{array}{c}\text { Number of sampled } \\
\text { individuals }\end{array}$ & Hatching period & $\begin{array}{l}\text { Mean ML } \\
(\mathrm{mm}) \pm \mathrm{SD}\end{array}$ & $\begin{array}{c}\text { Mean age } \\
\text { (days) } \pm \mathrm{SD}\end{array}$ \\
\hline \multirow{2}{*}{ Jwarm } & 113 (JWSG) & Jun-Nov & \multirow[b]{2}{*}{$254.4 \pm 45.5$} & \multirow[b]{2}{*}{$294.4 \pm 30.5$} \\
\hline & 47 (JCSG) & Jun-Oct & & \\
\hline \multirow{2}{*}{ Jcold } & 4 (JWSG) & Dec & \multirow{2}{*}{$251.1 \pm 31.0$} & \multirow{2}{*}{$328.7 \pm 46.0$} \\
\hline & 15 (JCSG) & Dec-May & & \\
\hline Taiwan & 32 (TSG) & Aug-Mar & $273.3 \pm 39.1$ & $243.9 \pm 20.0$ \\
\hline
\end{tabular}

(b) Sneakers

\begin{tabular}{ccccc}
\hline Cohort & $\begin{array}{c}\text { Number of sampled } \\
\text { individuals }\end{array}$ & Hatching period & $\begin{array}{c}\text { Mean ML } \\
(\mathrm{mm}) \pm \mathrm{SD}\end{array}$ & $\begin{array}{c}\text { Mean age } \\
(\text { days }) \pm \text { SD }\end{array}$ \\
\hline \multirow{2}{*}{ Jwarm } & 52 (JWSG) & Jul-Nov (JWSG) & $152.8 \pm 47.1$ & $254.4 \pm 37.3$ \\
& $101(\mathrm{JCSG})$ & Jun-Oct (JCSG) & & \\
Jcold & 24 (JWSG) & Dec-Apr (JWSG) & $166.3 \pm 37.6$ & $287.2 \pm 39.5$ \\
Taiwan & $101(\mathrm{JCSG})$ & $\begin{array}{c}\text { Dec-May (JCSG) } \\
\text { Aug-Mar }\end{array}$ & $128.5 \pm 37.0$ & $233.0 \pm 35.8$ \\
\hline
\end{tabular}

\subsection{Age, size and growth rate}

The mean ML of consorts showed no significant difference among cohorts $(F=2.608, P=0.076)$, but the mean age of consorts in the Taiwan cohort was significantly younger than that of consorts in the Japanese cohorts $(F=50.841, P<0.0001)$. The mean $\mathrm{ML}$ of sneakers was largest in the Jcold cohort, followed by Jwarm, with the Taiwan cohort the smallest $(F=23.623, P<0.0001)$; while the mean age of sneakers was youngest in the Jwarm cohort and oldest in the Taiwan cohort ( $F=60.455, P<0.0001)$. Sneakers matured at a smaller size and a younger age than consorts in all cohorts. The size range of sneakers clearly overlapped with that of immature males and partly with consorts for all cohorts (Figure 2). The age range of sneakers completely overlapped with that of both immature males and consorts.

Growth rates in $M L\left(G_{L}\right)$ and BW $\left(G_{W}\right)$ differed among cohorts (Figure 3). For consorts and sneakers, the Taiwan cohort showed the highest growth rates (both $\mathrm{G}_{L}$ and $\mathrm{G}_{W}$ ), followed by the Jwarm and Jcold cohorts (consorts: $G_{L} F=72.58, P<0.0001 ; G_{W} F=73.12, P<0.0001$; sneakers: $G_{L} F=42.29, P<0.0001$; 
$\left.\mathrm{G}_{W} \mathrm{~F}=46.20, P<0.0001\right)$. The Taiwanese immature males, too, had the highest growth rate, followed by the Jcold and then Jwarm cohorts $\left(G_{L}: \mathrm{F}=226.67, P<0.0001, G_{W}: F=205.34, P<0.0001\right)$. This is consistent with the result that the statolith increment widths of the Taiwanese cohort were wider than those of the Japanese cohorts, especially during the early stage of life (50-150 days) (Figure 4).

Growth rates also varied for different maturity statuses within each cohort. In the Jwarm cohort, the growth rate of consorts was slightly lower than that of immature males and sneakers $\left(\mathrm{G}_{\mathrm{L}}: \mathrm{F}=4.42, P=\right.$ $\left.0.013 ; G_{W}: F=26.49, P<0.0001\right)$. In the Jcold cohort, immature males had the highest growth rate $\left(G_{L}: F\right.$ $\left.=33.16, P<0.0001 ; G_{W}: F=42.00, P<0.0001\right)$, and sneakers had the same $G_{L}$ as consorts but a slightly higher $G_{W}$. Accordingly, sneakers had slightly wider statolith increment widths in the early life stage $(\sim$ 200 days) than those of consorts in the Jwarm and Jcold cohorts (Figure 4a, b). In the Taiwanese cohort, immature males had the highest $\mathrm{G}_{L}$ (followed by consorts, with sneakers the lowest; $\mathrm{F}=77.09, P<$ $0.0001)$; and also the highest $G_{W}$, but consort and sneaker males showed no difference in $G_{W}(F=69.08$, $P<0.0001)$. Similarly, Taiwanese consorts had much wider statolith increment widths around 50-150 days than those of sneakers during the same period (Figure 4c).

\subsection{Energy allocation}

Body condition and reproductive condition were compared among different maturity statuses in three cohorts (Figure 5). In the Jwarm cohort, sneakers had the best body condition, followed by immature males, with consorts the poorest $(F=16.123, P<0.0001)$; and sneakers had the best reproduction condition, followed by consorts, and immature males the poorest $(F=132.084, P<0.0001)$. In the Jcold cohort, sneakers had the best body condition, followed by immature males, with consorts the poorest $(F=$ $30.038, P<0.0001)$. There was no difference in reproductive condition between consorts and immature males, while sneakers had the highest reproductive condition $(F=30.406, P<0.0001)$. In the Taiwan cohort, consorts showed the poorest body condition $(F=13.15, P<0.0001)$, while sneakers and immature males had the same level of body condition. Similarly, sneakers showed the greatest reproductive condition, followed by consorts, and immature males the poorest $(F=73.97, P<0.0001)$. In general, sneakers had better body and reproductive condition than consorts in all cohorts.

Gonado-somatic energy allocation of consorts and sneakers in different cohorts are shown in Figure 6. For both consorts and sneakers, the poorest body condition was observed in the Jwarm cohort (consorts: $\mathrm{F}=10.34, P<0.0001$; sneakers: $\mathrm{F}=38.18, P<0.0001)$, and the highest reproductive condition was observed in the Taiwan cohort (consorts: $\mathrm{F}=6.87, P=0.0013$; sneakers: $\mathrm{F}=23.08, P<0.0001$ ).

ML-MW residuals were positively correlated with ML-GW residuals in the Jwarm cohort (consorts: $r=$ 0.665, $P<0.0001$; sneakers: $r=0.479, P<0.0056$ ) and Taiwan cohort (consorts: $r=0.263, P=0.001$; sneakers: $r=0.302, P=0.002)$; while they were negatively correlated in sneakers $(r=-0.177, P=0.049)$, and there was no strong correlation in consorts of the Jcold cohort $(r=0.28, P=0.25)$.

\section{Discussion}


For short-lived species with ARTs in the temperate area, date of birth can influence ART expression, because individuals born at different periods experience different growth conditions before maturation (the birthdate effect: Pastres et al., 2002; Fagundes et al., 2015; Welsh et al., 2017). The high proportion of consorts appearing in the JWSG could be accounted for by the large number of consorts comprising the Jwarm cohort. Similarly, the occurrence of few consorts among the Jcold cohort led to low numbers of consorts in the JCSG. In contrast, the relatively high incidence of sneakers in the JCSG might benefit from not only those that hatched from Jcold cohort, but also the early additional recruitment of the Jwarm cohort with faster growth and of younger age, implying a strong environmental influence on the lifespan of sneakers but not consorts. The greatly overlapping hatching periods of consorts and sneakers in the Taiwan group is presumably due to the relatively stable subtropical environment off Taiwan.

The reproductive success of an ART is measured by its proportion in the population (Taborsky and Brockmann, 2010). Squid are annual species with high phenotypic plasticity, so the ratio of each ART in the population can easily change as a result of environmental conditions. For the $U$. edulis population in Japan, the consort-to-sneaker ratio shifted between water temperature periods: that is, a consortdominant warm period and a sneaker-dominant cold period. Water temperature cannot be the only environmental factor affecting the appearance of ARTs in males because there was also a large bias in favour of sneakers even in the warmer Taiwan cohort (which had SST characteristics closer to those of the Jwarm cohort; see section 2.1, above).

Social conditions such as female mate preference may explain the ratio of ARTs in different cohorts. In swordtail fish with large consorts and small sneakers, larger females have an overall preference for large males (Rios-cardenas et al., 2007; Morris et al., 2010). Therefore, when there is a larger proportion of smaller females, the mating advantage of sneakers will increase. Uroteuthis edulis females mature over a wider size range with larger size variation in the Jcold (range 97-323 mm, mean ML $201.2 \pm 49.6 \mathrm{~mm}$ ) and Taiwan (87-294mm, average size: $179.4 \pm 46.6 \mathrm{~mm})$ cohorts than in the Jwarm cohort (range 101$277 \mathrm{~mm}$, mean ML $188.6 \pm 31.9 \mathrm{~mm}$ ) (Pang, unpublished data). Hence, females may accept sneakers as mates more readily when females mature over a wide range with a larger proportion of small individuals.

In many fish species, body size is regarded as one of the main factors to determine the relative reproductive success of each ART (Ryan and Causey, 1989; Bleeker et al., 2017). Body size is also a trigger to switch ARTs ontogenetically from small sneakers to large consorts (Alonzo and Warner, 2000). In $\mathrm{H}$. bleekeri, consorts and sneakers can be roughly distinguished by a body size division around ML 200-220 mm (Iwata and Sakurai, 2007). However, the size range of sneakers greatly overlaps with that of consorts in Japanese cohorts of $U$. edulis, and overlaps only slightly in the Taiwan cohort. Thus, body size seems not to be an effective morphological indicator of male ARTs in $U$. edulis. The size difference between consorts and sneakers in the Taiwan cohort might be due to the early maturation of sneakers in the warm Taiwanese water but more data are required to test this hypothesis.

Maturity has been assumed to be a polygenetic character that can be modelled as a threshold trait, where maturation is dependent on the attainment of a certain growth rate, body size or a combination of factors 
(Hutchings and Myers, 1994; Piché et al., 2008). Variation of size and age at maturity is common across taxa and is influenced by both genetic and environmental factors, which are often associated with ARTs (Thomaz et al., 1997; Piché et al., 2008; Berejikian et al., 2011; McKinney et al., 2020). The lack of differences in mean $M L$ of $U$. edulis consorts among cohorts implies that there might be a body size threshold to trigger sexual maturation of consorts. Taiwanese consorts showed a younger age at maturity than Japanese consorts, which might result from the higher water temperature leading to faster growth and subsequent early maturation. However, the mean $\mathrm{ML}$ and age of sneakers at capture decreased with a warmer hatching environment in the present study. As observed in $U$. edulis consorts, size-dependent maturation might lead to a delay of maturation when the ambient environmental conditions are unfavorable for growth (Policansky, 1983). However, size advantage is not necessary for sneakers, so they are more flexible in terms of body size and age at maturity when responding to different environment contexts.

A growth-rate threshold has also been proposed as a factor determining male ARTs (Hutchings and Myers, 1994). Individuals with a higher growth rate attain maturity earlier to adopt one reproductive tactic, while individuals with a growth rate lower than a threshold adopt another tactic (Berejikian et al., 2011). Significant genetic effects were found on growth rate at the early stage and subsequent occurrence of reproductive tactic in fish species (Berejikian et al., 2011; Wirtz-Ocana et al, 2013). In U. edulis, growth rate $\left(G_{L}\right.$ or $\left.G_{W}\right)$ slightly differed among different maturity statuses in the same cohort in this study. Immature males displayed a higher growth rate in both $M L\left(G_{D}\right)$ and $B W\left(G_{W}\right)$ than consorts and sneakers in the Jcold and Taiwan cohorts, which implies that somatic growth might slow down after maturation (Arkhipkin et al., 2000; Arkhipkin and Roa-Ureta, 2005). Growth rate in both $M L\left(G_{\nu}\right)$ and $B W\left(G_{W}\right)$ was significantly different between consorts and sneakers in each cohort, though the observed difference was small. However, comparisons of statolith increment widths between $U$. edulis consorts and sneakers in their early life stage (50 150 days) indicate that individuals achieved quite different growth rates in the early life stage, which might contribute to the determination of male ARTs. However, the early life growth of consorts was slower than that of sneakers in Japan but the opposite occurred in Taiwan, indicating that growth of early life stages is not the sole mechanism determining ARTs but that a complex combination of many factors is probably involved.

Although the mechanism remains unclear, environments obviously influence growth rate and consequently choices of ARTs in $U$. edulis males. The instantaneous growth rates $M L\left(G_{D}\right)$ and $B W\left(G_{W}\right)$ are mean values across the lifetime of the squids, so it is difficult to detect any environmental influences after the attainment of maturity. Elevated temperature greatly accelerates growth rate and shortens the lifespan of many squid species (Pecl and Jackson, 2008). Temperature conditions during early development play a key role in individual growth (Forsythe, 2004; Moreno et al., 2007), which explains why the Taiwan cohort grew the fastest, followed by the Jwarm cohort, with the Jcold cohort showing the slowest growth for both consorts and sneakers.

Energy allocation in males with ARTs usually involves trade-offs, as energy resources and reserves are finite. The fitness of males pursuing ARTs seems to be balanced: small-size sneakers mature earlier to 
obtain a higher probability to reproduce while large-size consorts achieve greater copulation success. One of the most common examples of gonado-somatic energy allocation is a trade-off between behavioral and gonadal investments (Taborsky 1994, 1998). For instance, guard (consort) males of the round goby invest highly in large body size while sneakers direct resources to the gonadal tissues at the expense of body size (Marentette et al., 2009). In all cohorts of $U$. edulis, sneakers invest more energy in both somatic and gonadal growth compared to consorts. After maturation, $U$. edulis consorts invest less energy in somatic growth, while sneakers continue to invest in somatic growth.

In some fish species, large males show a strong decrease in their energy reserves, which are the source of energy required for reproduction. These reserves are recharged slowly or not at all if no food is eaten during the breeding season: so these individuals are regarded as 'capital breeders.' In contrast, smallsized males use concurrent food intake to provide the energy for a reproductive attempt, replenishing energy faster for upcoming adoption of other mating tactics, and as such are regarded as 'income breeders' (Malavasi et al., 2004; von Kuerthy et al., 2015). A positive relationship between somatic growth and gonadal growth of $U$. edulis consorts implies that energy might be greatly used for conducting mating behaviors, sacrificing body reserves and gonadal development and probably only a small amount of food is eaten during the breeding season. In contrast to fish species, few males intermediate between consorts and sneakers have been reported in squid species (Apostólico and Marian, 2019).

Accompanying relatively high investment in gonadal development, a positive correlation of sneaker gonado-somatic energy allocation in Jwarm and Taiwan cohorts implies that sneakers might consume food to maintain somatic growth after maturation for more sneaking opportunities through aggressive interactions (Kawase et al., 2017). Indeed, most individuals sampled during the present study had empty stomachs due to the rapid digestion in squid species (Semmens, 2002), so it is difficult to support the hypothesis of gonado-somatic energy allocation patterns of $U$. edulis consorts and sneakers through estimating food intake condition from stomach weight at capture. In addition, Laskowski et al. (2020) have pointed out that a trade-off between somatic and gonadal growth tends to be found when environmental conditions are challenging and resources are depleted during the early life stages, which might explain the negative correlation between gonado-somatic energy allocation of sneakers in the Jcold cohort. The scarcity of consorts among sampled specimens in the Jcold cohort might be explained by the absence of a strong correlation with gonado-somatic energy allocation. However, the results reflect only the investment in gonadal growth in terms of gonad weight, while energy flows to mating behaviors, such as agonistic male-male competition, courtship, mating and guarding, were not quantified in this study.

It seems that energy allocation patterns of $U$. edulis males are inherent within ARTs, however, the environment also plays a significant role in gonado-somatic energy allocation. Consorts and sneakers responded consistently to temperature influence in terms of energy allocation. Males in the Jwarm cohort showed the poorest body condition, which might be caused by experiencing a long cold water period following hatching during a warm period. In a warmer environment, such as that experienced by the Taiwan population, males would invest the least in gonadal growth. Although the mechanism of gonadosomatic allocation patterns that consorts and sneakers adopt in different temperatures cannot be 
completely understood from this study, U. edulis consorts and sneakers showed consistent responses to various temperature conditions, indicating the great impact of water temperature on the occurrence of ARTs.

Although the maturation of consorts seems to be size-dependent, and differences of growth rate between consorts and sneakers in the early life stage might be crucial to determine ARTs in $U$. edulis, this study focused on the temperature influence on male squid LHTs after their ARTs had been determined. Overall, sneakers showed greater flexibility of LHTs than consorts at different temperatures, and the dominance of sneakers in Taiwan might indicate that sneakers have an advantage under conditions of global warming. If so, it can be expected that the frequency of sneakers occurrence in natural populations of $U$. edulis will increase as global warming progresses.

\section{Declarations}

\section{Acknowledgments}

We thank Prof. Yoshiro Watanabe for valuable discussions, Dr. Kei Zenimoto for his help with sample collecting, Seiya Kudo for his help in the laboratory, and Prof. lan Gleadall for editing this manuscript.

\section{Funding}

This study was supported financially by Japan Society for the Promotion of Science Kakenhi grants $17 \mathrm{~K} 15309$ and $19 \mathrm{H} 03029$ to Y.I., and 20JI4792 to Y.P.

\section{Author information}

\section{Affiliations}

Atmosphere and Ocean Research Institute, University of Tokyo, 5-1-5 Kashiwanoha, Kashiwa, Chiba, 2778564, Japan;

Yumeng Pang, Tomohiko Kawamura \& Yoko Iwata

Institute of Marine Affairs and Resource Management, National Taiwan Ocean University, Keelung, 20224, Taiwan (R.O.C.);

Chih-Shin Chen

Center of Excellence for the Oceans, National Taiwan Ocean University, Keelung, 20224, Taiwan (R.O.C.) Chih-Shin Chen

\section{Contributions}


YP: conceptualization, data collection, statistics analysis, funding acquisition, writing-original draft, writing-review and editing; CC: supervision, writing-review and editing; TK: supervision, writing-review and editing; Yl: conceptualization, funding acquisition, methodology, writing-review and editing.

\section{Corresponding author}

Correspondence to Yumeng Pang (stillwater1314@yahoo.com)

\section{Ethics declarations}

\section{Conflicts of interest}

No conflict of interest.

\section{Ethical approval}

This research was conducted in accordance with Japanese Code of Conduct for Scientific Practice. All applicable international, national and institutional guidelines for sampling and experimental use of organisms for the study have been followed.

\section{Consent to participate}

All authors consent to participate

\section{Consent to publication}

All authors and all institutions that provided funding and to which the authors belong consent to the publication of this study.

\section{References}

1. Alonzo SH, Warner RR (2000) Female choice, conflict between the sexes and the evolution of male alternative reproductive behaviours. Evol. Ecol. Res., 2(2), 149-170.

2. Apostolico LH, Marian JE (2018) Dimorphic male squid show differential gonadal and ejaculate expenditure. Hydrobiologia, 808(1), 5-22. https://doi.org/10.1007/s10750-017-3145-z

3. Apostólico LH, Marian JE (2019) Behavior of "intermediate" males of the dimorphic squid Doryteuthis pleii supports an ontogenetic expression of alternative phenotypes. Front. Physiol., 10, 1180. https://doi.org/10.3389/fphys.2019.01180

4. Arkhipkin A (1996) Geographical variation in growth and maturation of the squid IIlex coindeth (Oegopsida, Ommastrephidae) off the north-west African coast. J. Mar. Biolog. Assoc. U.K., 76(4), 1091-1106. https://doi.org/10.1017/S0025315400040984

5. Arkhipkin, Al (2005) Statoliths as 'black boxes' (life recorders) in squid. Mar. Freshwater Res., 56, 573583. https://doi.org/10.1071/MF04158 
6. Arkhipkin Al, Roa-Ureta R (2005) Identification of ontogenetic growth models for squid. Mar. Freshw. Res., 56(4), 371-386. https://doi.org/10.1071/MF04274

7. Arkhipkin A, Jereb P, Ragonese S (2000) Growth and maturation in two successive seasonal groups of the short-finned squid, Illex coindetii from the Strait of Sicily (central Mediterranean). ICES J. Mar. Sci., 57(1), 31-41. https://doi.org/10.1006/jmsc.1999.0488

8. Arkhipkin, A, Laptikhovsky, V, Golub, A (1999) Population structure and growth of the squid Todarodes sagittatus (Cephalopoda: Ommastrephidae) in north-west African waters. J. Mar. Biolog. Assoc. U.K., 79(3), 467-477. https://doi.org/10.1017/S0025315498000599

9. Berejikian BA, Van Doornik DM, Atkins JJ (2011) Alternative Male Reproductive Phenotypes Affect Offspring Growth Rates in Chinook Salmon, Trans. Am. Fish. Soc., 140:5, 1206-1212 https://doi.org/10.1080/00028487.2011.618351

10. Bleeker, K, De Jong, K, Van Kessel, N, Hinde, CA, Nagelkerke, LA (2017) Evidence for ontogenetically and morphologically distinct alternative reproductive tactics in the invasive Round Goby Neogobius melanostomus. PLoS One, 12(4), e0174828. https://doi.org/10.1371/journal.pone.0174828

11. Ceriola L, Jackson GD (2010) Growth, hatch size and maturation in a southern population of the Ioliginid squid Loliolus noctiluca. J. Mar. Biolog. Assoc. U.K., 90(4), 755-767. https://doi.org/10.1017/S0025315409991445

12. Chemshirova I, Hoving HJ, Arkhipkin A (2021) Temperature effects on size, maturity, and abundance of the squid IIlex argentinus (Cephalopoda, Ommastrephidae) on the Patagonian Shelf. Estuar. Coast. Shelf Sci., 255, 107343. https://doi.org/10.1016/j.ecss.2021.107343

13. Chen CS, Chiu TS (2003) Variations of life history parameters in two geographical groups of the neon flying squid, Ommastrephes bartramii, from the North Pacific. Fish. Res., 63(3), 349-366.

14. Ching TY, Chen CS, Wang CH (2019) Spatiotemporal variations in life-history traits and statolith trace elements of Sepioteuthis lessoniana populations around northern Taiwan. J. Mar. Biolog. Assoc. U.K., 99(1), 203-213.

15. Doubleday, ZA, Prowse, TA, Arkhipkin, A, Pierce, GJ, Semmens, J, Steer, M, Gillanders, BM et al (2016) Global proliferation of cephalopods. Curr. Bio., 26(10), 406-407. https://doi.org/10.1016/j.cub.2016.04.002

16. Fagundes T, Simões MG, Saraiva JL, Ros AF, Gonçalves D, Oliveira RF (2015) Birth date predicts alternative life-history pathways in a fish with sequential reproductive tactics. Funct. Ecol., 29(12), 1533-1542. https://doi.org/10.1111/1365-2435.12465

17. FAO Fisheries and Aquaculture Department. (2016) The state of world fisheries and aquaculture. Food and Agriculture Organization of the United Nations.

18. Forsythe JW (2004) Accounting for the effect of temperature on squid growth in nature: from hypothesis to practice. Mar. Freshw. Res., 55(4), 331-339.

19. Hanlon, RT, Maxwell, MR, Shashar, N (1997) Behavioral dynamics that would lead to multiple paternity within egg capsules of the squid Loligo pealei. Biol. Bull., 193(2), 212-214. 
20. Hoving HJT, Gilly WF, Markaida U, Benoit-Bird KJ, Brown ZW, Daniel P et al (2013) Extreme plasticity in life-history strategy allows a migratory predator (jumbo squid) to cope with a changing climate. Glob. Change Biol., 19(7), 2089-2103. https://doi.org/10.1111/gcb.12198

21. Hutchings, JA., Myers, RA (1994) The evolution of alternative mating strategies in variable environments. Evol. Ecol., 8(3), 256-268.

22. Ibáñez CM, Sepúlveda RD, Ulloa P, Keyl F, Pardo Gandarillas MC (2015) The biology and ecology of the jumbo squid Dosidicus gigas (Cephalopoda) in Chilean waters: a review. Lat. Am. J. Aquat. Res., 43(3): 402-414. https://doi.org/10.3856/vol43-issue3-fulltext-2

23. Ichii T, Mahapatra K, Sakai M, Okada Y (2009) Life history of the neon flying squid: effect of the oceanographic regime in the North Pacific Ocean. Mar. Ecol. Prog. Ser., 378, 1-11. https://doi.org/10.3354/meps07873

24. Iwata Y, Sakurai Y (2007) Threshold dimorphism in ejaculate characteristics in the squid Loligo bleekeri. Mar. Ecol. Prog. Ser., 345, 141-146. https://doi.org/10.3354/meps06971

25. Iwata Y, Munehara H, Sakurai Y (2005) Dependence of paternity rates on alternative reproductive behaviors in the squid Loligo bleekeri. Mar. Ecol. Prog. Ser., 298, 219-228. doi:10.3354/meps298219

26. Iwata, Y, Sauer, WH, Sato, N, Shaw, PW (2018) Spermatophore dimorphism in the chokka squid Loligo reynaudii associated with alternative mating tactics. J Molluscan Stud., 84(2), 157-

162. https://doi.org/10.3389/fphys.2019.01281

27. Iwata, Y., Sato, N., Hirohashi, N., Watanabe, Y., Sauer, WH, Shaw, PW (2021). Sperm competition risk affects ejaculate strategy in terms of sperm number but not sperm size in squid. J. Evol. Biol., 34(9), 1352-1362. https://doi.org/10.1111/jeb.13894

28. Jackson, GD (2004) Advances in defining the life histories of myopsid squid. Mar. Freshwater Res., 55, 357-365. https://doi.org/10.1071/MF03152

29. Jackson, GD, Forsythe, JW (2002) Statolith age validation and growth of Loligo plei (Cephalopoda: Loliginidae) in the north-west Gulf of Mexico during spring/summer. J. Mar. Biolog. Assoc. U.K, 82(4), 677-678. https://doi.org/10.1017/S0025315402006069

30. Jackson GD, Steer BM, Wotherspoon S, Hobday AJ (2003) Variation in age, growth and maturity in the Australian arrow squid Nototodarus gouldi over time and space what is the pattern?. Mar. Ecol. Prog. Ser., 264, 57-71. https://doi:10.3354/meps264057.

31. Jackson GD, Wotherspoon S, McGrath-Steer BL (2005) Temporal population dynamics in arrow squid Nototodarus gouldi in southern Australian waters. Mar. Biol., 146(5), 975-983. https://doi.org/10.1007/s00227-004-1491-7

32. Jackson G, Moltschaniwskyj N (2002) Spatial and temporal variation in growth rates and maturity in the Indo-Pacific squid Sepioteuthis lessoniana (Cephalopoda: Loliginidae). Mar. Biol., 140(4), 747754. https://doi.org/10.1007/s00227-001-0746-9

33. Japan Meteorological Agency, Fukuoka Regional Headquarters (undated). Japan Coastal Sea Surface Temperatures (Northern Kyushu, Southern Kyushu and Amami Archipelago Regions) Past 
Data for Area 605.

https://www.data.jma.go.jp/fukuoka/kaiyo/kaikyo/mean_sst/data/txt/area605.txt

34. Jereb, P, Roper, CF (2010) Cephalopods of the world-an annotated and illustrated catalogue of cephalopod species known to date. Vol 2. Myopsid and oegopsid squids (No. 2). FAO.

35. Kawase S, Hayashi T, Matsumoto Y, Takegaki T (2017) Testis size variation within sneaker males of the dusky frillgoby Bathygobius fuscus (Gobiidae): effects of within-tactic competition. Biol. J. Linn. Soc., 122(2), 394-399.

36. Laskowski, KL, Moiron, M, Niemelä, P (2020) Integrating behavior in life-history theory: allocation versus acquisition?. Trends Ecol. Evol., 36(2), 132-138. https://doi.org/10.1016/j.tree.2020.10.017

37. Lin D, Chen X, Chen Y, Fang Z (2015) Sex-specific reproductive investment of summer spawners of Illex argentinus in the southwest Atlantic. Invertebr., 134(3), 203-213.

https://doi.org/10.1111/ivb.12088

38. Marentette JR, Fitzpatrick JL, Berger RG, Balshine S (2009) Multiple male reproductive morphs in the invasive round goby (Apollonia melanostoma). J. Great Lakes Res. J 35(2), 302-308. https://doi.org/10.1016/j.jglr.2009.01.009

39. Marian JE, Apostólico LH, Chiao CC, Hanlon RT, Hirohashi N, Iwata Y et al (2019) Male alternative reproductive tactics and associated evolution of anatomical characteristics in loliginid squid. Front. Physiol., 10, 1281. https://doi.org/10.3389/fphys.2019.01281

40. Malavasi S, Fiorin R, Franco A, Torricelli P (2004) Somatic energy storage and reproductive investment in the grass goby Zosterisessor ophiocephalus. J. Mar. Biolog. Assoc. U.K., 84(2), 455459.

41. McGrath Steer BL, Jackson GD (2004) Temporal shifts in the allocation of energy in the arrow squid, Nototodarus gouldi: sex-specific responses. Mar. Biol., 144, 1141-

1149 https://doi.org/10.1007/s00227-003-1289-z

42. McKinney, GJ, Seeb, JE, Pascal, CE, Schindler, DE, Gilk-Baumer, SE, Seeb, LW (2020) Y-chromosome haplotypes are associated with variation in size and age at maturity in male Chinook salmon. Evol. Appl., 13(10), 2791-2806. https://doi.org/10.1111/eva.13084

43. Moreno A, Azevedo M, Pereira J, Pierce GJ (2007) Growth strategies in the squid Loligo vulgaris from Portuguese waters. Mar. Biol. Res., 3(1), 49-59. https://doi.org/10.1080/17451000601129115

44. Morris MR, Rios-Cardenas O, Brewer J (2010) Variation in mating preference within a wild population influences the mating success of alternative mating strategies. Anim. Behav., 79(3), 673678. https://doi.org/10.1016/j.anbehav.2009.12.018

45. Naud MJ, Sauer WH, McKeown NJ, Shaw PW (2016) Multiple mating, paternity and complex fertilisation patterns in the chokka squid Loligo reynaudii. PLoS One, 11(2), e0146995. https://doi.org/10.1371/journal.pone.0146995

46. Natsukari, Y., Nakanose, T., \& Oda, K. (1988). Age and growth of loliginid squid Photololigo edulis (Hoyle, 1885). J. Exp. Mar. Biol. Ecol., 116(2), 177-190. https://doi.org/10.1016/00220981(88)90054-8 
47. Pastres R, Pranovi F, Libralato S, Malavasi S, Torricelli P (2002) 'Birthday effect'on the adoption of alternative mating tactics in Zosterisessor ophiocephalus: evidence from a growth model. J. Mar. Biolog. Assoc. U.K., 82(2), 333-337. https://doi.org/10.1017/S0025315402005520

48. Pang, Y, Chen, CS, Iwata, Y (2020) Variations in female swordtip squid Uroteuthis edulis life history traits between southern Japan and northern Taiwan (Northwestern Pacific). Fish Sci, 86(6), 10051017. https://doi.org/10.1007/s12562-020-01465-7

49. Patterson, KR (1988) Life history of Patagonian squid Loligo gahi and growth parameter estimates using least-squares fits to linear and von Bertalanffy models. Mar. Ecol. Prog. Ser., 47: 65-74.

50. Pecl GT, Jackson GD (2005) The potential effects of climate change on southern calamary in Tasmanian waters: biology, ecology and fisheries. Marine Research Laboratory, University of Tasmania.

51. Pecl GT, Moltschaniwskyj NA (2006) Life history of a short-lived squid (Sepioteuthis australis): resource allocation as a function of size, growth, maturation, and hatching season. ICES J. Mar. Sci., 63(6), 995-1004. https://doi.org/10.1016/j.icesjms.2006.04.007

52. Pecl GT, Moltschaniwskyj NA, Tracey SR, Jordan AR (2004) Inter-annual plasticity of squid life history and population structure: ecological and management implications. Oecologia 139, 515-524.

53. Piché J, Hutchings JA, Blanchard W (2008) Genetic variation in threshold reaction norms for alternative reproductive tactics in male Atlantic salmon, Salmo salar. Proc. Royal Soc. B P ROY SOC B-BIOL SCl, 275(1642), 1571-1575 https://doi.org/10.1098/rspb.2008.0251

54. Pierce GJ, Valavanis VD, Guerra A, Jereb P, Orsi-Relini L, Bellido JM et al (2008) A review of cephalopod-environment interactions in European Seas. Hydrobiologia, 612(1), 49-70.

55. Pierce GJ, Zuur AF, Smith JM, Santos MB, Bailey N, Chen CS, Boyle PR (2005) Interannual variation in life-cycle characteristics of the veined squid (Loligo forbesi) in Scottish (UK) waters. Aquat. Living Resour.18(4), 327-340.

56. Policansky D (1983) Size, age and demography of metamorphosis and sexual maturation in fishes. Am. Zool., 23(1), 57-63 https://doi.org/10.1093/icb/23.1.57

57. Rios-Cardenas O, Tudor MS, Morris MR (2007) Female preference variation has implications for the maintenance of an alternative mating strategy in a swordtail fish. Anim. Behav., 74(3), 633640. https://doi.org/10.1016/j.anbehav.2007.01.002

58. Rocha F, Guerra A (1996) Signs of an extended and intermittent terminal spawning in the squids Loligo vulgaris Lamarck and Loligo forbesi Steenstrup (Cephalopoda: Loliginidae). J. Exp. Mar. Biol. Ecol., 207(1-2), 177-189. https://doi.org/10.1016/S0022-0981(96)02631-7

59. Ryan MJ, Causey BA (1989) "Alternative" mating behavior in the swordtails Xiphophorus nigrensis and Xiphophorus pygmaeus (Pisces: Poeciliidae). Behav. Ecol. Sociobiol., 24(6), 341348. https://doi.org/10.1007/BF00293262

60. Semmens, JM (2002) Changes in the digestive gland of the loliginid squid Sepioteuthis lessoniana (Lesson 1830) associated with feeding. J. Exp. Mar. Biol. Ecol., 274(1), 19-

39. https://doi.org/10.1016/S0022-0981(02)00165-X 
61. Shashar, N., \& Hanlon, R. T. (2013). Spawning behavior dynamics at communal egg beds in the squid Doryteuthis (Loligo) pealeii. J. Exp. Mar. Biol. Ecol., 447, 65-74.

https://doi.org/10.1016/j.jembe.2013.02.011

62. Taborsky M (1994) Sneakers, satellites, and helpers: parasitic and cooperative behavior in fish reproduction. Adv. Study Behav., 23(1), e100.

63. Taborsky M (1998) Sperm competition in fish: bourgeois' males and parasitic spawning. Trends Ecol. Evol., 13(6), 222-227. https://doi.org/10.1016/S0169-5347(97)01318-9

64. Taborsky M, Brockmann HJ (2010) Alternative reproductive tactics and life history phenotypes. In Animal behaviour: evolution and mechanisms (pp. 537-586) https://doi.org/10.1007/978-3-64202624-9_18

65. Thomaz DM, Beall E, Burke T (1997) Alternative reproductive tactics in Atlantic salmon: factors affecting mature parr success. Proc. Royal Soc. B P ROY SOC B-BIOL SCl, 264(1379), 219-226. https://doi.org/10.1098/rspb.1997.0031

66. Toyofuku T, Wada T (2018) Chromatophore arrangement and photophore formation in the early development of swordtip squid Uroteuthis (Photololigo) edulis. Fish Sci., 84(1), 9-15. https://doi.org/10.1007/s12562-017-1145-6

67. Vidal E A, DiMarco FP, Wormuth JH, Lee PG (2002) Influence of temperature and food availability on survival, growth and yolk utilization in hatchling squid. Bull. Mar. Sci., 71(2), 915-931

68. Villanueva, R (2000) Differential increment-deposition rate in embryonic statoliths of the loliginid squid Loligo vulgaris. Mar. Biol., 137: 161-168. https://doi.org/10.1007/s002270000323

69. von Kuerthy C, Tschirren L, Taborsky M (2015) Alternative reproductive tactics in snail shell-brooding cichlids diverge in energy reserve allocation. Ecol. Evol., 5(10), 2060-2069.

70. Wang, K. Y., Liao, C. H., \& Lee, K. T. (2008). Population and maturation dynamics of the swordtip squid (Photololigo edulis) in the southern East China Sea. Fish. Res., 90(1-3), 178-186. https://doi.org/10.1016/j.fishres.2007.10.015

71. Wang, KY, Lee, KT, Liao, CH (2010) Age, growth and maturation of swordtip squid (Photololigo edulis) in the southern East China Sea. J. Mar. Sci. Technol., 18(1), 99-105.

72. Welsh DP, Wiegmann DD, Angeloni LM, Newman SP, Miner JG, Baylis JR (2017) Condition-dependent reproductive tactics in male smallmouth bass: evidence of an inconsistent birthdate effect on early growth and age at first reproduction. J. Zool., 302(4), 244-251. https://doi.org/10.1111/jzo.12454

73. Wirtz-Ocaňa S, Schütz D, Pachler G, Taborsky M (2013) Paternal inheritance of growth in fish pursuing alternative reproductive tactics. Ecol. Evol, 3(6), 1614-1625. https://doi.org/10.1002/ece3.570

74. Yu W, Chen X, Yi Q, Tian S (2015) A review of interaction between neon flying squid (Ommastrephes bartramii) and oceanographic variability in the North Pacific Ocean. J. Ocean Univ., 14(4), 739-748.

\section{Figures}




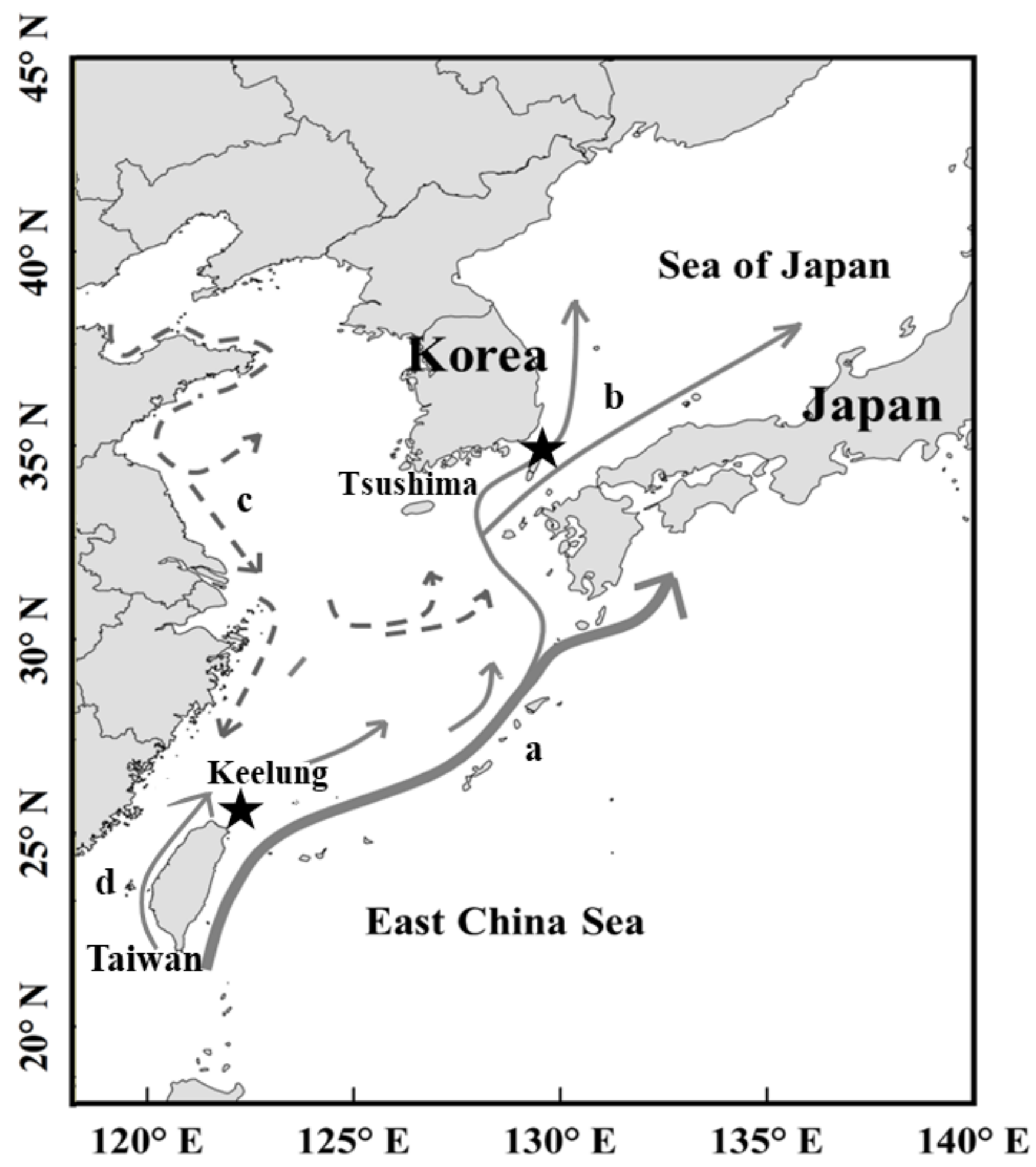

Figure 1

Sampling localities (stars) off the Tsushima Islands (Japan) and off Keelung (Taiwan). a, Kuroshio current; b, Tsushima warm current; c, East China Sea mainland coastal current; d, Taiwan Strait warm current. 

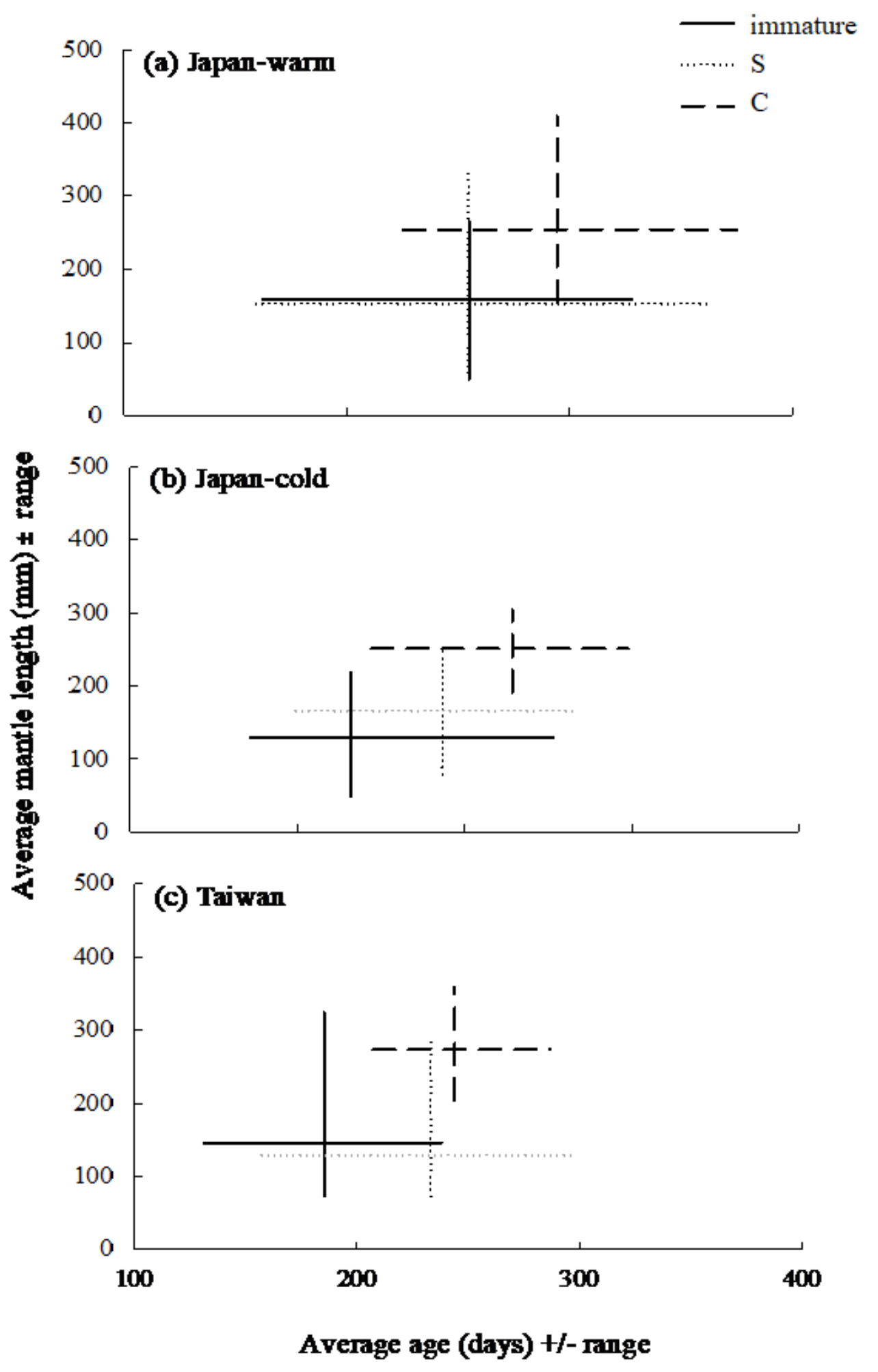

Figure 2

Relationship between age and length of immature males, consorts (C) and sneakers (S) in different cohorts. Horizontal lines show age range; vertical lines show mantle length range. 

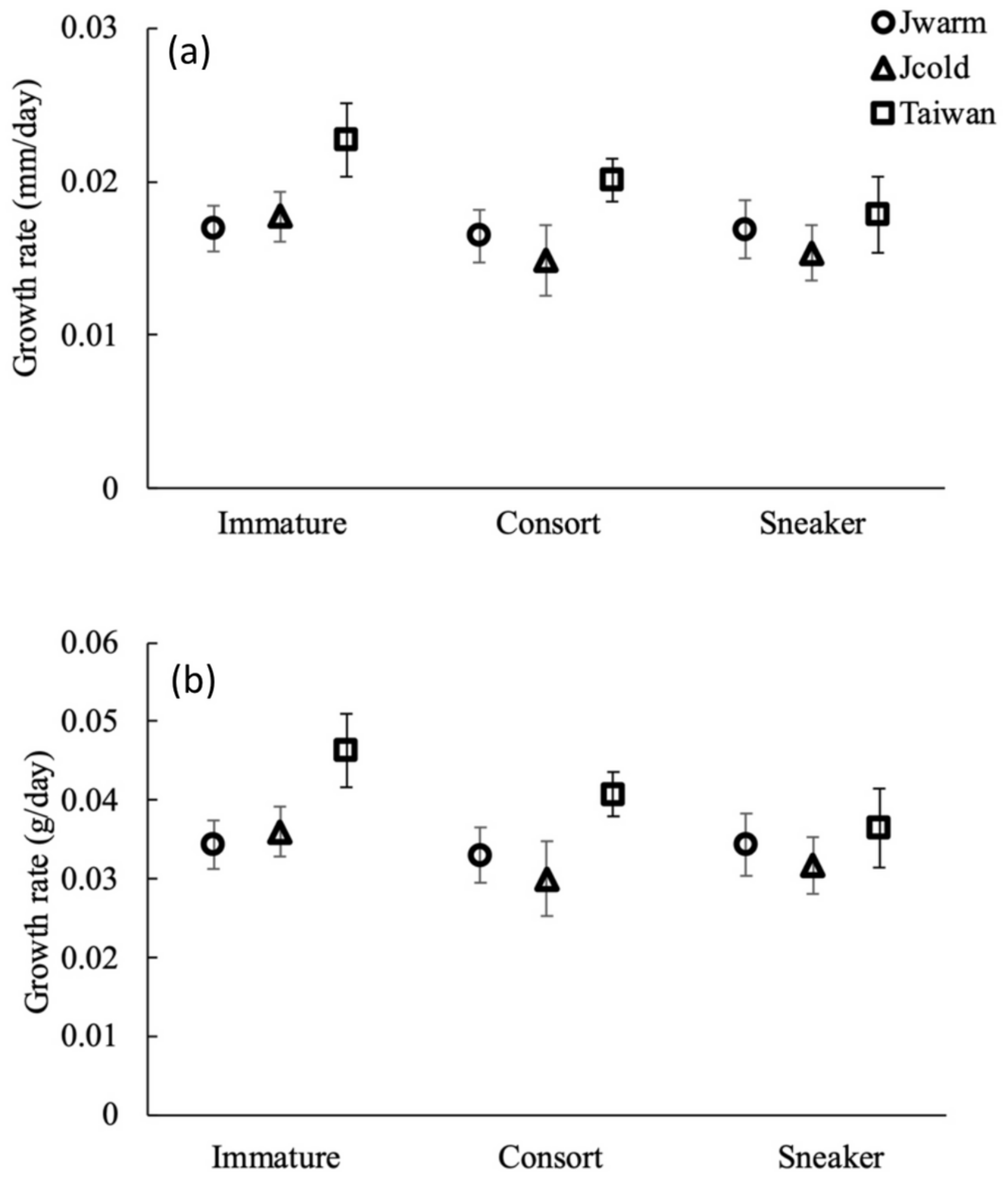

Figure 3

Growth rate of males of different maturity status in different cohorts: (a) Growth rate in mantle length (GL, mm/day); (b) Growth rate in wet-weight (GW, g/day). 


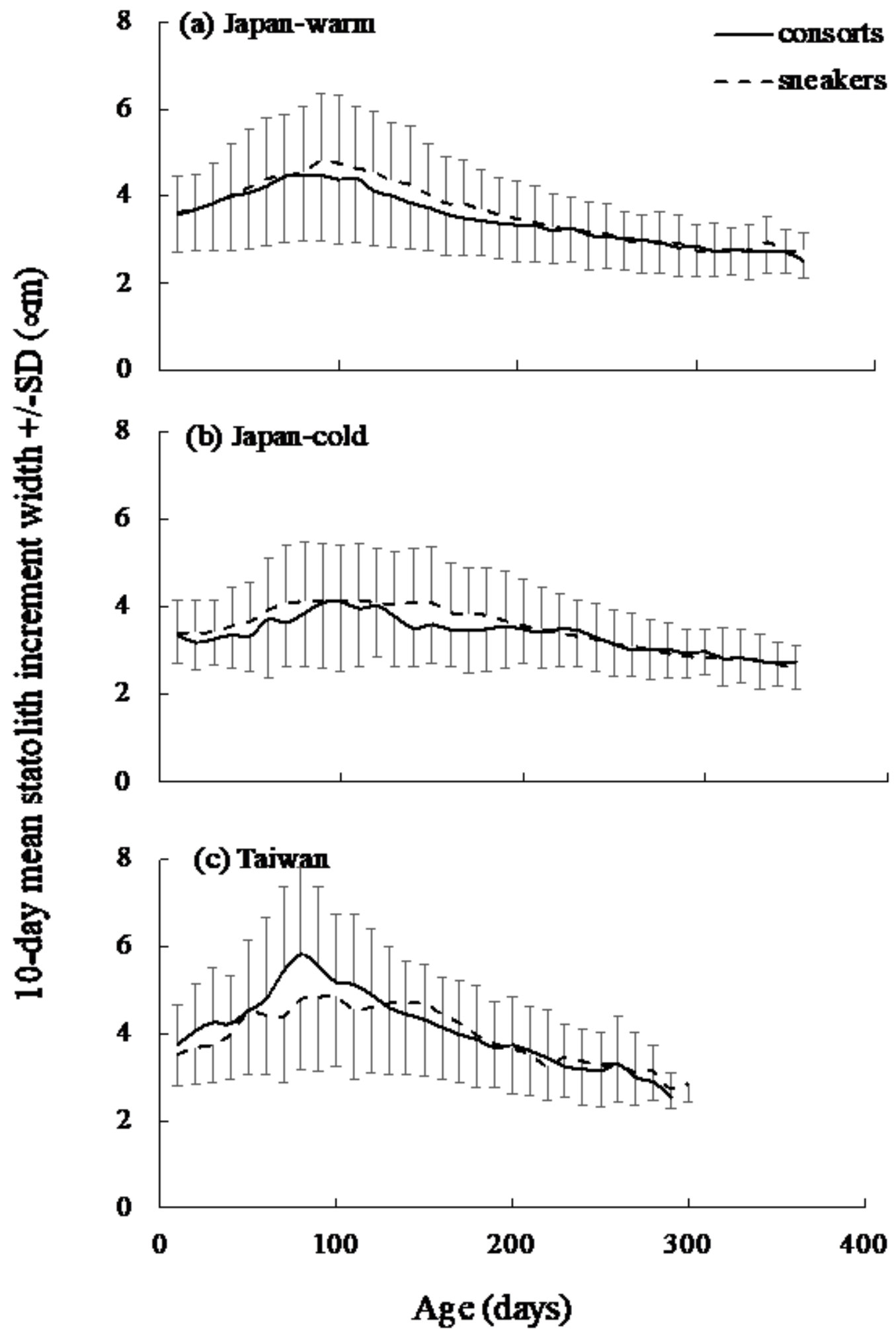

Figure 4

10-days mean statolith increment width of consorts and sneakers from different cohorts. 

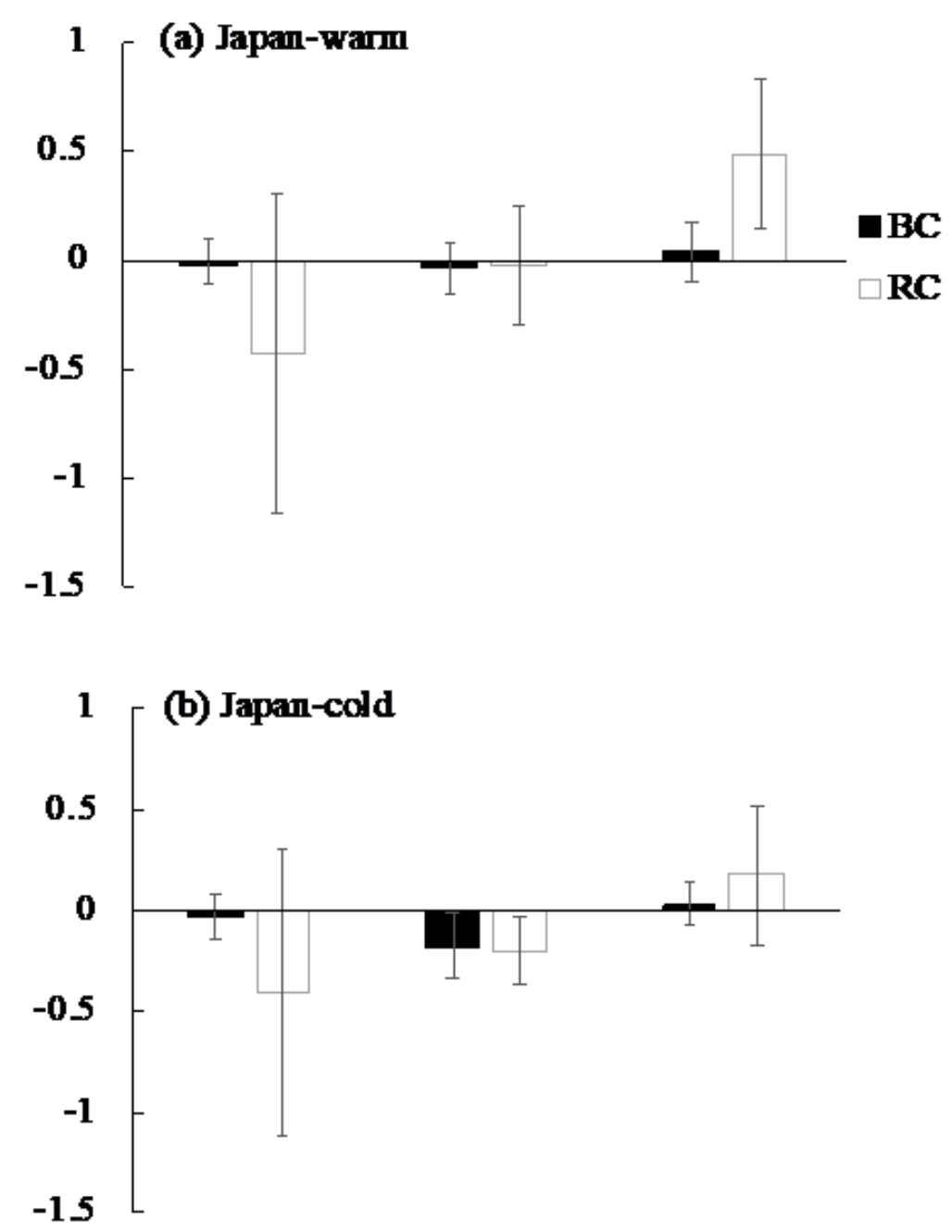

(c) Tajwan

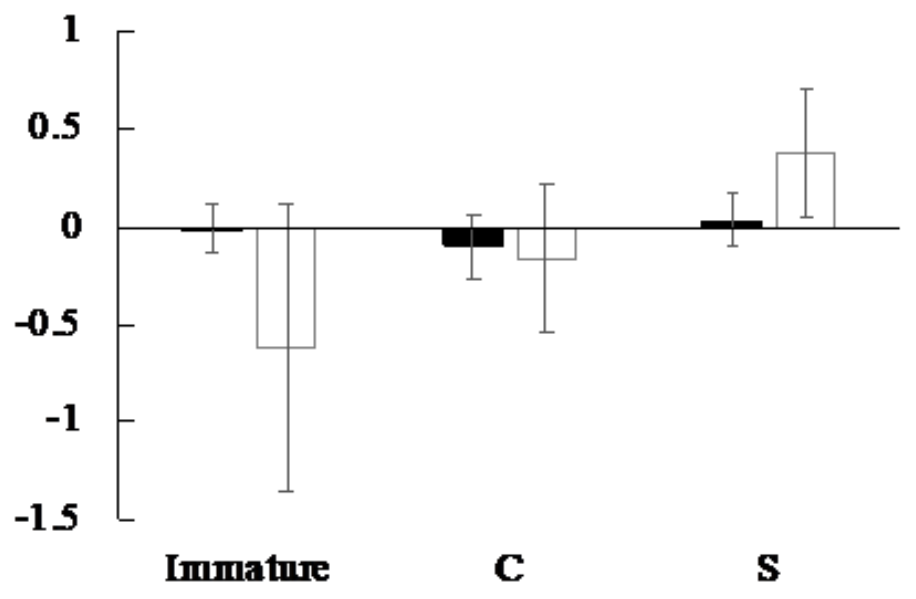

Figure 5

Body condition (BC) and reproductive condition (RC) for males of different maturity statuses in different cohorts. Immature, immature males; C, consorts; S, sneakers. (For definitions of BC and RC, see Materials and Methods section 2.3). 


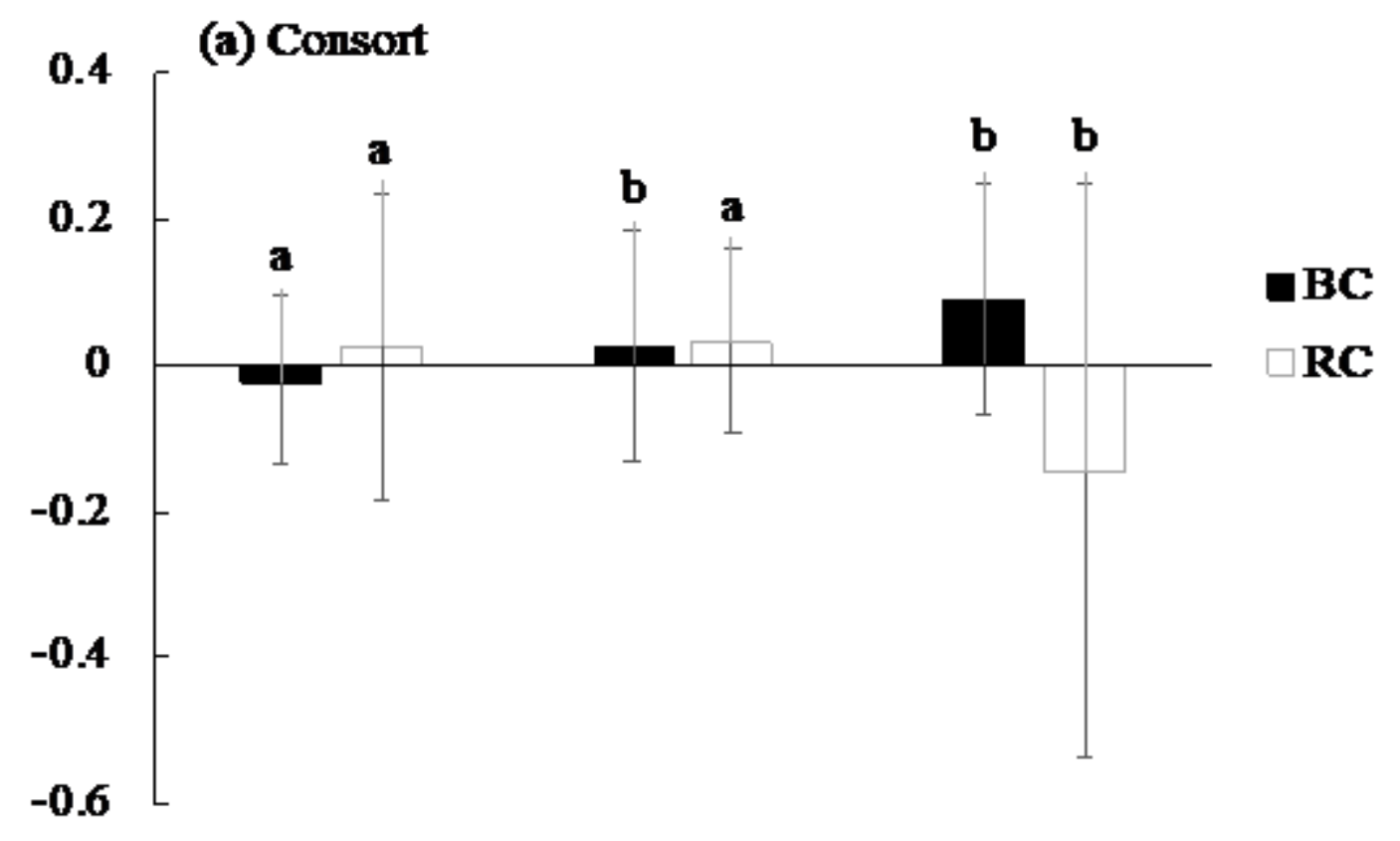

(b) Sneaker

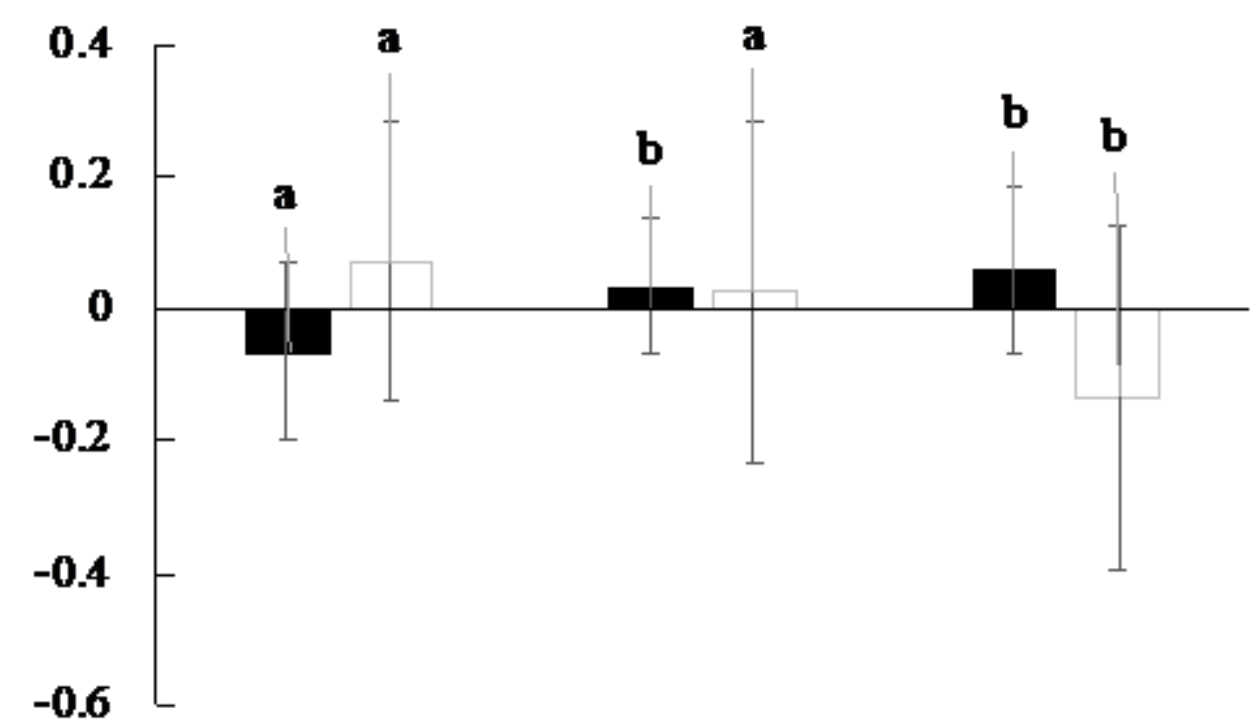

\section{Japan-warm Japan-cold $\quad$ Taiwan}

Figure 6

Body condition (BC, black bars) and reproductive condition (RC, white bars) of consorts (a) and sneakers (b) from different cohorts. 